\title{
Pre-treatment of biomasses using magnetised sulfonic acid catalysts
}

\author{
Yane Ansanay, Praveen Kolar, Ratna Sharma-Shivappa, Jay Cheng, Sunkyu Park, Consuelo Arellano \\ Department of Biological and Agricultural Engineering, North Carolina State University, Raleigh, NC, USA
}

\begin{abstract}
There is a significant interest in employing solid acid catalysts for pre-treatment of biomasses for subsequent hydrolysis into sugars, because solid acid catalysts facilitate reusability, high activity, and easier separation. Hence the present research investigated pretreatment of four lignocellulosic biomasses, namely Switchgrass (Panicum virgatum L 'Alamo'), Gamagrass (Tripsacum dactyloides), Miscanthus (Miscanthus $\times$ giganteus) and Triticale hay (Triticale hexaploide Lart.) at $90^{\circ} \mathrm{C}$ for $2 \mathrm{~h}$ using three carbon-supported sulfonic acid catalysts. The catalysts were synthesized via impregnating p-Toluenesulfonic acid on carbon (regular) and further impregnated with iron nitrate via two methods to obtain magnetic A and magnetic B catalysts. When tested as pre-treatment agents, a maximum total lignin reduction of $17.73 \pm 0.63 \%$ was observed for Triticale hay treated with magnetic A catalyst. Furthermore, maximum glucose yield after enzymatic hydrolysis was observed to be $203.47 \pm 5.09 \mathrm{mg} \mathrm{g}^{-1}$ (conversion of $65.07 \pm 1.63 \%$ ) from Switchgrass treated with magnetic A catalyst. When reusability of magnetised catalysts were tested, it was observed that magnetic A catalyst was consistent for Gamagrass, Miscanthus $\times$ Giganteus and Triticale hay, while magnetic B catalyst was found to maintain consistent yield for switchgrass feedstock. Our results suggested that magnetised solid acid catalyst could pre-treat various biomass stocks and also can potentially reduce the use of harsh chemicals and make bioenergy processes environment friendly.
\end{abstract}

Correspondence: Praveen Kolar, Department of Biological and Agricultural Engineering, Box 7625, North Carolina State University, Raleigh, NC 27695, USA.

Tel.: +1.919.513.9797 - Fax: +1.919.515.7760.

E-mail: pkolar@ncsu.edu

Key words: Magnetic catalysts; lignocellulosic biomass; pre-treatment; hydrolysis.

Acknowledgements: the authors would like to thank the generous financial support of the North Carolina State University College of Agricultural and Life Sciences Dean's enhancement grant.

Received for publication: 26 August 2016.

Accepted for publication: 23 December 2016.

CCopyright Y. Ansanay et al., 2017

Licensee PAGEPress, Italy

Journal of Agricultural Engineering 2017; XLVIII:594

doi:10.4081/jae.2017.594

This article is distributed under the terms of the Creative Commons Attribution Noncommercial License (by-nc 4.0) which permits any noncommercial use, distribution, and reproduction in any medium, provided the original author(s) and source are credited.

\section{Introduction}

Lignocellulosic biomass possesses distinctive advantage as one of the renewable sources of energy due to high carbohydrate content. In addition to being inexpensive, lignocellulosic biomass offers sustainability and a high potential to reduce greenhouse gas emissions (Perlack et al., 2005; Zhou et al., 2011). However, one of the main challenges in converting biomass into alcohols involves disruption of the complex structure of the biomass to obtain fermentable monomeric sugars (Kumar et al., 2009; Agbor et al., 2011). Usually, physico-chemical pre-treatments are required to ensure that biomass becomes accessible to enzymes for hydrolysis either via removal of lignin or solubilisation of hemicellulose (Mosier et al., 2005; Alvira et al., 2010). Several physical and chemical pre-treatments using heat, acids, bases, organic solvents and ionic liquids have been developed and studied extensively. Although, chemical pre-treatment techniques are attractive due to the higher reaction efficiency and excellent mass transfer capabilities (Guo et al., 2012), use of chemical agents leads to various environmental issues and also requires expensive unit operations on the downstream side of the process (Peña et al., 2014). Therefore, reusable pre-treatment agents that also minimise environmental impacts are required. One such option is to use solid acid catalyst as pre-treatment agent for biomass (Hara, 2010; Guo et al., 2012).

Utilising solid acid catalysts can potentially address some of these aforementioned challenges associated with liquid pre-treatments because solid acid catalysts allow for mild operating conditions and moderately high selectivity. In addition, solid acid catalysts allow for simple separation from products by vacuum filtration or magnetic separation (Lai et al., 2011; Guo et al., 2013; Peña et al., 2014). Further, the catalysts may be used repeatedly for the reaction without neutralisation, therefore decreasing energy consumption and waste (Zhou et al., 2011). Hence, there is a growing interest in developing solid catalysts for pre-treatment of biomass. Researchers have been exploring solid acid catalysts for pre-treatment of biomass streams. For example, Peña et al. (2014) reported glucose yield of 59\% achieved from corn stover treated used propyl-sulfonic acid-functionalised nanoparticle catalyst at $160^{\circ} \mathrm{C}$ for $60 \mathrm{~min}$ followed by the addition of $2 \mathrm{~mL}$ of accelerase enzyme along with $2.5 \mathrm{~g}$ wet corn stover for $24 \mathrm{~h}$ hydrolysis. The study also reported that as pre-treatment temperature increased to $180^{\circ} \mathrm{C}$, the yield of glucose increased reached the maximum of $90 \%$. In a different study, macroalgae cellulose residue was treated used Dowex (TM) Dr-G8 solid catalyst followed by enzymatic hydrolysis where two enzymes were employed (45 FPU (filter paper unit)) $\mathrm{g}^{-1}$ of cellulase and $52 \mathrm{CBU}$ (cellobiase unit) $\mathrm{g}^{-1}$ of $\beta$ glucosidase) to produce glucose yield at around $94 \%$ even after 5 reuses (Tan and Lee, 2015). Our group at North Carolina State University is also interested in synthesis and testing of solid acid catalysts for biomass processing. In the recent past, we explored niobium and carbon-supported sulfonic acid catalytic pre-treatment of biomasses (Ansanay et al., 2014, 2016). However, one of the problems associated with pre-treatment of biomass with solid 
acid catalysts is separation of biomass from the catalysts as biomass and catalyst particles will be intimately mixed after pretreatment. One possible approach to separate the catalyst from biomass is to employ magnetised catalysts and subsequently use magnetic force to separate the biomass from catalyst. However, there is little information on how these magnetic solid acid catalysts perform as pre-treatment agents for different biomass stocks. Therefore the present research was performed to systematically evaluate activated carbon-supported sulfonic acid catalysts for pretreatment of Switchgrass (Panicum virgatum L 'Alamo'), Gamagrass (Tripsacum dactyloides), Miscanthus (Miscanthus $\times$ giganteus) and Triticale hay (Triticale hexaploide Lart.). Based on the surface chemistry of the solid acid catalysts, we hypothesise that activated carbon-supported sulfonic acid catalysts can pretreat various biomasses for subsequent enzymatic hydrolysis.

\section{Materials and methods}

\section{Lignocellulosic feedstock}

Switchgrass (Panicum virgatum L 'Alamo'), Gamagrass (Tripsacum dactyloides), Miscanthus (Miscanthus $\times$ giganteus) and Triticale hay (Triticale hexaploide Lart.) were used as feedstocks in this research. Switchgrass was harvested in mid July 2011 from North Carolina State University Field Laboratory in Reedy Creek Road Raleigh, NC and subsamples were field cured for 3 days. Gamagrass variety was harvested towards the end of July 2012, and the postharvest samples were oven dried at $50^{\circ} \mathrm{C}$ for 72 h. Miscanthus was harvested from the Mountain Horticultural Crops Research and Extension Centre (Mills River, NC) in December 2011 and oven dried at $45^{\circ} \mathrm{C}$ for $72 \mathrm{~h}$. The biomasses, Switchgrass, Gamagrass, and Miscanthus were ground to pass a 2 $\mathrm{mm}$ sieve. Furthermore, Triticale hay sample was collected from the field at Central Agricultural Research Centre of Montana State University. Due to the inherent properties of Triticale, the sample was ground to pass $1 \mathrm{~mm}$ sieve. All biomasses were placed in sealed plastic bags and stored until further use. The initial moisture contents were Switchgrass, Gamagrass, Miscanthus and Triticale hay $7.98,6.54,6.44$ and $6.53 \%$, respectively. In addition, the feedstocks were analysed for lignin and main carbohydrates content using standard methods (Sluiter et al., 2008) (Table 1).

\section{Sulfonic solid acid catalysts preparation}

\section{Regular activated carbon-supported sulfonic acid catalyst}

Catalyst used in this study was prepared by impregnating $60 \mathrm{~g}$ of activated carbon with p-Toluenesulfonic acid solution. pToluenesulfonic acid solution was prepared by mixing $67 \mathrm{~g}$ of $\mathrm{p}$ Toluenesulfonic acid into $100 \mathrm{~mL}$ of deionized water. The activated carbon was soaked in the acid solution for $48 \mathrm{~h}$, separated by filtration, followed by drying for $2 \mathrm{~h}$ at $105^{\circ} \mathrm{C}$ and calcination for $2 \mathrm{~h}$ at $250^{\circ} \mathrm{C}$.

\section{Magnetic activated carbon sulfonic acid catalyst}

The magnetic activated carbon sulfonic acid catalyst was synthesized using two methods. In the first method, $30 \mathrm{~g}$ of activated carbon (fine) was stirred in a $50 \mathrm{~mL}$ deionized water solution containing $12 \mathrm{~g}$ of iron (III) nitrate, similar to the procedure described by Guo et al. (2013). The $\mathrm{pH}$ of the solution was adjusted to 10 by adding $3 \mathrm{M}$ of sodium hydroxide solution. The mixture was stirred at $200 \mathrm{rpm}$ at room temperature for $24 \mathrm{~h}$, after which the solid was filtered and calcined at $400^{\circ} \mathrm{C}$ under nitrogen flow for $3 \mathrm{~h}$ to obtain magnetically activated carbon. Subsequently, $20 \mathrm{~g}$ of magnetic carbon was mixed with an aqueous solution containing $20 \mathrm{~mL}$ deionized water, $13.5 \mathrm{~g}$ of p-Toluenesulfonic acid, and $20 \mathrm{~mL}$ mercaptoacetic acid for $24 \mathrm{~h}$ at room temperature at $200 \mathrm{rpm}$. At the end of 24-h period, 3M-sodium hydroxide solution was added until the $\mathrm{pH}$ of the slurry reached 7 . At this stage, the solid was separated from the slurry and dried at $80^{\circ} \mathrm{C}$ for $12 \mathrm{~h}$ followed by calcination under nitrogen flow at $400^{\circ} \mathrm{C}$ for $3 \mathrm{~h}$. Subsequently, $12 \mathrm{~g}$ of the solid was immersed into $20 \mathrm{~mL}$ of deionized water and $20 \mathrm{ml}$ of hydrogen peroxide was added dropwise. The mixture was stirred at $200 \mathrm{rpm}$ at room temperature for $12 \mathrm{~h}$. The solid was separated and dried again at $80^{\circ} \mathrm{C}$ for $16 \mathrm{~h}$ to obtain the final product, which was named magnetic, activated carbon-supported p-Toluenesulfonic acid catalyst and named Magnetic A. In the second method of preparation, similar procedure (as above) was employed. However, granular sodium hydroxide was used instead of liquid. In addition, during the final step, $10 \mathrm{~mL}$ of hydrogen peroxide was added twice instead of dropwise addition. Subsequently, the mixture was dried $\left(80^{\circ} \mathrm{C}\right)$ and calcined $(16 \mathrm{~h})$ to obtain of magnetic activated carbonsupported p-Toluenesulfonic acid catalyst and named Magnetic B.

\section{Pre-treatment}

Pre-treatment was performed in batch reactors placed on a hot plate capable of heating and mixing the reactor contents. Biomass and catalyst were mixed for $2 \mathrm{~h}$ at $90^{\circ} \mathrm{C}$, stirred at $350 \mathrm{rpm}$. After pre-treatment, catalyst was separated from biomass. For regular catalyst pre-treatment, the separation was performed simple filtration followed by the solid wet biomass separation using vacuum filtration. For magnetised catalyst pre-treatment, catalysts particles were extracted via conventional long magnetic retriever followed by the separation of solid wet biomass using vacuum filtration. The catalyst was stored for subsequent use and pre-treated biomass was hydrolysed.

\section{Sugar analysis}

Soluble polysaccharide in the liquid hydrolysate after pretreatment consisted of both simple sugars and sugars oligomer. Simple sugars such as glucose and xylose were measured via YSI 2950 Biochemistry Analyzer (YSI Incorporated, Yellow Springs, $\mathrm{OH}$, USA). Typically, $1 \mathrm{~mL}$ of each sample was prepared in an Eppendorf tube followed by exposing the sample to the enzymeimmobilised sensor to obtain the concentrations of glucose and xylose in $\mathrm{g} \mathrm{L}^{-1}$. To determine total oligomer, all sugars oligomers

Table 1. Initial compositional analysis of four feedstock (dry basis).

\begin{tabular}{lccc} 
Biomass/Composition & Glucan (\%) & Xylan (\%) & Acid soluble lignin (\%) \\
'Alamo' Switchgrass & $28.14 \pm 0.32$ & $13.47 \pm 0.28$ & $3.21 \pm 0.12$ \\
Gamagrass & $30.18 \pm 0.64$ & $12.88 \pm 0.59$ & $2.56 \pm 0.04$ \\
\hline Miscanthus $\times$ giganteus & $37.04 \pm 0.21$ & $11.79 \pm 0.10$ & $1.54 \pm 0.06$ \\
Triticale hay & $27.97 \pm 0.52$ & $13.29 \pm 0.54$ & $3.29 \pm 0.07$ \\
\hline
\end{tabular}


in the hydrolysate were expressed as monomeric sugar by adapting 4\% acid hydrolysis NREL procedures (Sluiter et al., 2006) as below:

Liquefaction $=$ Total oligomer + CSS

Simple sugars $=$ Glucose

Carbohydrate simple sugar $(\mathrm{CSS})=$ Glucose $\times 0.9$

Total oligomer $=($ Glucose $\times 0.9)+($ Xylose $\times 0.88)$

In the present context (Eqs. 1-4), liquefaction referred to a mixture of total oligomers and carbohydrate simple sugar (glucose), while total oligomers consisted of short polymers including xylose oligomer (from xylan) and glucose oligomer (from glucan).

\section{Enzymatic hydrolysis}

Enzymatic hydrolysis was performed at $50^{\circ} \mathrm{C}$ for $72 \mathrm{~h}(150$ rpm). Biomass samples ( $1 \mathrm{~g}$ dry basis) were mixed with $20 \mathrm{fpu}$ of Cellic Ctec 2 (Novozymes, NA) (activity $\sim 119 \mathrm{fpu} / \mathrm{mL}$ ), corresponding to $3.5 \% \mathrm{w} / \mathrm{w}$ (g protein enzyme $\mathrm{g}^{-1}$ dry biomass), and 50 $\mathrm{mM}$ of citric acid monohydrate buffer $(\mathrm{pH}=5.0)$ to bring the total volume of $20 \mathrm{~mL}$. To avoid microbial growth, $40 \mu \mathrm{g} \mathrm{mL}^{-1}$ of tetracycline was added as an antibiotic agent. After $72 \mathrm{~h}$, slurry samples were cooled down to $4^{\circ} \mathrm{C}$ and kept refrigerated until further analysis.

\section{Leaching tests}

To determine the extent of leaching of iron from the magnetic catalysts into the solution, leach tests for the liquid hydrolysate and pre-treated samples were performed via Perkin Elmer 3100 Atomic Absorption Spectroscopy. Final concentrations of iron adhered to the solid was reported in $\mathrm{mg} / \mathrm{g}$ while the iron in the liquid hydrolysates was expressed in $\mathrm{mg} \mathrm{L}^{-1}$.

\section{Statistics analysis}

All experiments were performed in triplicate. The data were analysed via SAS (SAS Institute Inc., Cary, NC, USA) Proc GLIMMIX method with Tukey adjustment. Data were analysed to study the effect of 3 different catalysts (regular, magnetic A and magnetic B) on 4 different biomasses (Switchgrass, Gamagrass, Miscanthus $\times$ giganteus, and Triticale hay). In addition, effect of reusability of magnetic catalysts was also tested by analysing the data for magnetisation procedure (2 levels: Magnetic A and
Magnetic B), feedstock (4 levels: Switchgrass, Gamagrass, Miscanthus $\times$ giganteus, Triticale hay) and reuse ( 2 levels: Reuse 1 and Reuse 2).

\section{Results and discussion}

\section{Effect of regular and magnetic catalytic pre-treatment on sugar and lignin}

After the pre-treatment, the magnetic catalysts were easily separated from biomass slurry via simple magnetic bar separators. Data for liquefaction, total oligomer and simple sugar of glucose for all biomasses tested are presented in Figure 1. It appeared that for Triticale hay regular and magnetic A catalysts facilitated solubilisation of carbohydrate (Figure 1A and B) corresponding to total sugar yields of $48.87 \pm 1.42 \mathrm{mg} \mathrm{g}^{-1}$ and $53.37 \pm 0.58 \mathrm{mg} \mathrm{g}^{-1}$ respectively. Wang et al. (2012) reported the use of perfluoroalkylsulfonic (PFS) and alkylsulfonic (AS) acid-functionalised magnetic nanoparticles for pre-treatment of wheat straw and attempted to solubilise hemicellulose. Their results show that after 24 -h reaction at lower temperature $\left(80^{\circ} \mathrm{C}\right), 3.5 \pm 0.1 \%$ and $1.0 \pm 0.2 \%$, of monosaccharides from xylan were obtained from the two catalysts. However, at higher temperature $\left(160^{\circ} \mathrm{C}\right.$ for $\left.2 \mathrm{~h}\right)$ xylose yields were observed to be $0.3 \%$ and $1.2 \%$ from PFS and AS catalysts respectively (Wang et al., 2012). In addition, Tan and Lee (2015) reported 0.77 g glucose (glucose yield of $0.77 \%$ ) in the pre-treatment liquid, when $100 \mathrm{~g}$ of macroalgae cellulosic residue was treated using Dowex (TM) Dr-G8 solid acid catalyst.

In comparison, the catalysts synthesized in our study were able to hydrolyse cellulose (glucan). Particularly, Magnetic B catalyst when used to pre-treat Triticale hay provided the highest glucose yield of $33.62 \pm 0.08 \mathrm{mg} \mathrm{g}^{-1}$ (glucose yield of $10.82 \pm 0.02 \%$ ) and maximum xylan oligomer of $1.79 \pm 0.2 \mathrm{mg} \mathrm{g}^{-1}$ in the liquid treatment, probably because smaller particles and the resulting higher surface area of Triticale (1-mm) may have allowed for effective enzymatic hydrolysis. However, the glucose yields obtained from other biomasses, such as Switchgrass, Gamagrass, and Miscanthus, using Magnetic B were substantially lower perhaps due to inherent differences in biomass structures.

The data was also analysed to investigate the effectiveness of these catalysts to disrupt lignin in the biomasses. As presented in
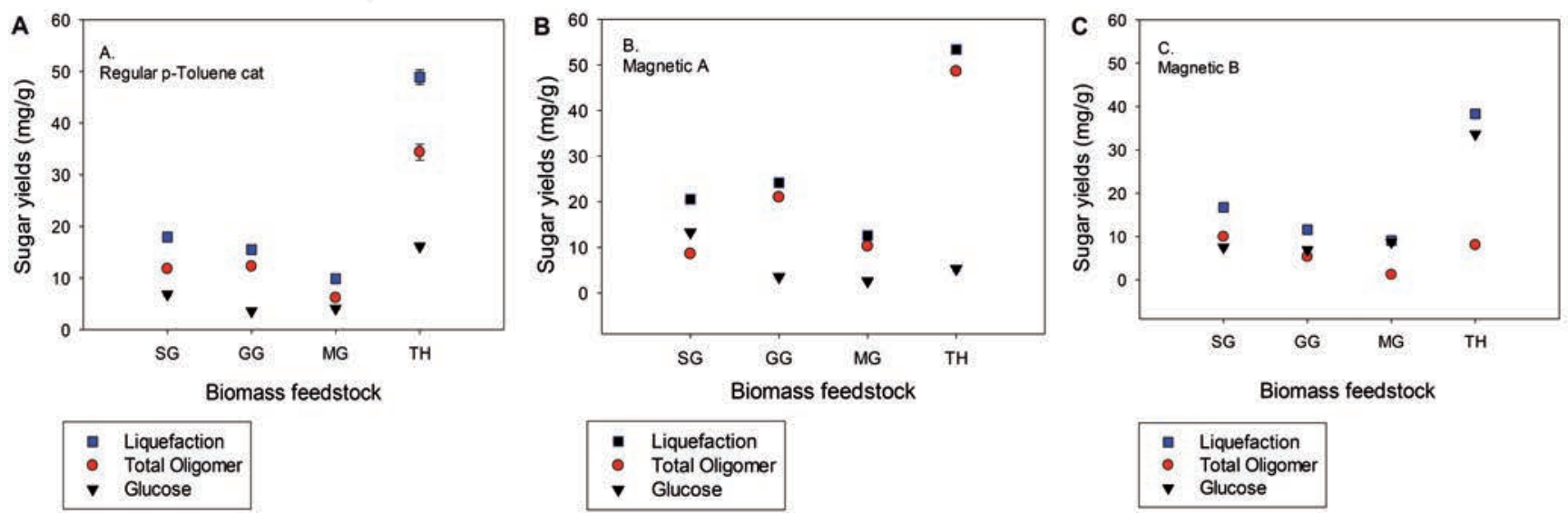

Figure 1. Sugars in the liquid after pretreatment with (A) regular catalyst, (B) Magnetic A and (C) Magnetic B catalyst. SG, Switchgrass; GG, Gamagrass; MG, Miscanthus $\times$ giganteus; TH, Triticale hay. 
Table 2, the highest reduction in total lignin was found in Triticale hay treated with magnetic A catalyst $(17.73 \pm 0.63 \%)$ followed by regular catalyst $(15.11 \pm 0.86 \%)$ probably due to smaller particle sise. Our results are similar to Chen et al. (2007) who reported the use of $0.5-2 \%$ alkali to obtain a $10.16-24.06 \%$ reduction in total lignin for Triticale hay.

\section{Effect of regular and magnetic catalysts on the enzy- matic hydrolysis stage}

As expected, each biomass responded to pre-treatment in different way due to inherent dissimilarities in biomass structures and compositions. The surface reaction between biomass and catalyst may have proceeded differently depending on the surface chemical and physical structure of lignin and cellulosic portion of each biomass. As presented from Figure 2, the glucose yields obtained after hydrolysis of switchgrass pre-treated with regular and magnetic $\mathrm{B}$ catalysts were similar $(\mathrm{P}=0.93)$.

However, for magnetic A, the yields were significantly higher than the yields obtained from regular and magnetic B catalysts $(\mathrm{P}<0.05)$. For Gamagrass there was no significant difference between the glucose yields for all three catalysts tested $(\mathrm{P}>0.1)$. Meanwhile, glucose yields for triticale hay treated with regular and magnetic A catalyst were not significantly different $(\mathrm{P}>0.05)$. Overall the maximum glucose yields (for all biomasses) ranged between $25.3 \pm 0.14 \%$ and $65.07 \pm 1.63 \%$ with Switchgrass providing with maximum glucose yields of $65.07 \pm 1.63 \%$. The yields observed from Miscanthus were between $25.3 \pm 0.14 \%$ $34.55 \pm 3.28 \%$. In comparison, Panneerselvam et al. (2013b) reported a maximum glucose yield (after enzymatic hydrolysis) of 13$26 \%\left(60-80 \mathrm{mg} \mathrm{g}^{-1}\right)$ when Miscanthus $\times$ giganteus was pre-treated with 40-58 $\mathrm{mg} \mathrm{L}^{-1}$ ozone using uniflow and reserve flow configurations. In addition, Miscanthus $\times$ giganteus treated with alkali followed by enzymatic hydrolysis was able to reach glucan conversion of $32.8 \pm 3.49 \%$ (Panneerselvam et al., 2013a). Similarly Gamagrass produced glucose yields between $160.4-174.33 \mathrm{mg} \mathrm{g}^{-1}$ (47.84 $\pm 0.26 \%$ - 51.99 $\pm 4.21 \%$; Figure 2$)$ after enzymatic hydrolysis with maximum yield that was obtained from Gamagrass treated with regular catalyst. The glucose yields obtained in our research are slightly lower than those reported by other researchers in liter- ature. For example, Xu et al. (2012) reported the glucose yields of 215.5-270.5 $\mathrm{mg} \mathrm{g}^{-1}$ (maximum glucan conversion of $67.7 \%$ ) after enzymatic hydrolysis from many varieties of Gamagrass treated with $1 \% \mathrm{NaOH}$ for $60 \mathrm{~min}$ at $121^{\circ} \mathrm{C}$. It may be noted that when the liquid and pre-treated biomass samples were analysed via atomic absorption spectroscopy, it was found that 0.4-6 $\mathrm{mmol} \mathrm{L}^{-1}$ and 4.5$7 \mathrm{mg} \mathrm{g}^{-1}$ of iron was present in liquid and pre-treated biomass respectively, suggesting that iron was leaching into the system due to agitation. Despite reports by Tejirian and $\mathrm{Xu}$ (2010) and Chen and $\mathrm{Fu}$ (2013) that iron may inhibit enzymatic hydrolysis our data suggested that Cellic Ctec 2 can still performed reasonably well. We theorize that the yields could be enhanced by employing a surfactant to minimise the effects of iron on enzymatic hydrolysis as proposed by $\mathrm{Chen}$ and $\mathrm{Fu}$ (2013). In addition, the amounts of xylose also increased between $11.48 \pm 3.66 \mathrm{mg} \mathrm{g}^{-1}-46.88 \pm 0.38 \mathrm{mg}$ $\mathrm{g}^{-1}$ after enzymatic hydrolysis even without the addition of xylanase (Table 3 ).

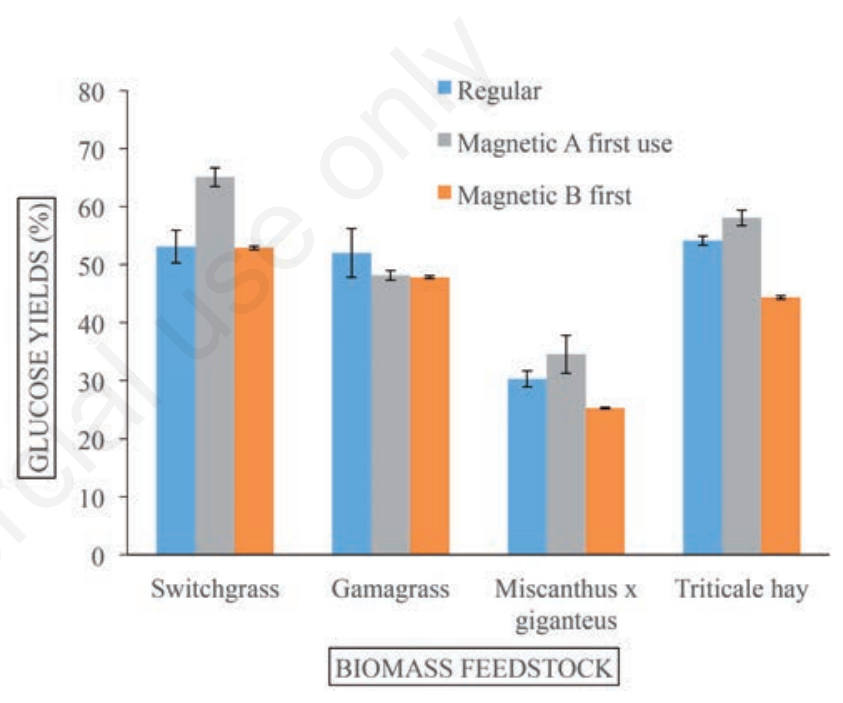

Figure 2. Glucose yields obtained after enzymatic hydrolysis of four different biomasses using three sulfonic acid catalysts.

Table 2. Total lignin reduction after pretreatment using sulfonic acid catalysts.

\begin{tabular}{|c|c|c|c|c|}
\hline Biomass feedstock & $\begin{array}{l}\text { Total lignin reduct } \\
\text { Regular }\end{array}$ & $\begin{array}{l}\text { retreatment } \\
\text { luenesulfoni } \\
\text { Magnetic A }\end{array}$ & Magnetic B & P-values \\
\hline Switchgrass & $10.02 \pm 0.95$ & $10.75 \pm 1.84$ & $9.50 \pm 1.02$ & 0.972 \\
\hline Gamagrass & $9.83 \pm 0.69$ & $13.02 \pm 0.19$ & $9.27 \pm 0.36$ & 0.005 \\
\hline Miscanthus $\times$ giganteus & $9.19 \pm 0.63$ & $11.76 \pm 0.82$ & $9.21 \pm 0.13$ & 0.046 \\
\hline Triticale hay & $15.11 \pm 0.86$ & $17.73 \pm 0.63$ & $12.25 \pm 0.34$ & 0.003 \\
\hline
\end{tabular}

Table 3. Xylose produced after enzymatic hydrolysis from four biomasses treated using p-Toluenesulfonic acid catalysts.

\begin{tabular}{lccccccc}
\hline Biomass feedstock & \multicolumn{2}{c}{$\begin{array}{c}\text { Xylose produced (mg g-1 dry biomass) } \\
\text { Regular }\end{array}$} & $\begin{array}{c}\text { Magnetic A } \\
\text { first use }\end{array}$ & $\begin{array}{c}\text { Magnetic A } \\
\text { second use }\end{array}$ & $\begin{array}{c}\text { Magnetic B } \\
\text { first use }\end{array}$ & $\begin{array}{c}\text { Magnetic B } \\
\text { second use }\end{array}$ & P-values \\
Switchgrass & $30.00 \pm 1.86$ & $37.00 \pm 1.80$ & $23.27 \pm 1.27$ & $20.93 \pm 0.48$ & $28.33 \pm 0.18$ & $<0.001$ \\
Gamagrass & $22.34 \pm 2.17$ & $24.80 \pm 1.50$ & $19.94 \pm 5.62$ & $19.85 \pm 0.07$ & $12.30 \pm 1.46$ & 0.093 \\
\hline Miscanthus $\times$ giganteus & $12.35 \pm 0.85$ & $13.85 \pm 0.24$ & $15.93 \pm 0.90$ & $11.48 \pm 3.66$ & $13.25 \pm 0.57$ & 0.483 \\
Triticale hay & $35.60 \pm 1.42$ & $46.88 \pm 0.38$ & $45.53 \pm 0.29$ & $29.80 \pm 0.23$ & $33.27 \pm 0.70$ & $<0.001$ \\
\hline
\end{tabular}




\section{Effect of reusability of magnetic catalysts on sugars yields produced at enzymatic hydrolysis}

The data suggested that when Magnetic A catalyst was reused twice to pre-treat biomasses, the glucose yields after hydrolysis of Gamagrass, Miscanthus $\times$ giganteus and Triticale hay were within $5 \%$ difference (Figure 3). Analysis of data using GLIMMIX procedure suggested that glucose yields (after enzymatic hydrolysis) from Gamagrass, Miscanthus $\times$ giganteus, and Triticale hay treated with magnetic A catalyst were not significantly different between first and second uses $(\mathrm{P}>0.05)$. In addition, the glucose yield for Switchgrass treated with magnetic A was found to decrease by $11.8 \%$ after first use.

The trend exhibited by Magnetic B, however was different. The data indicated that when Magnetic B catalyst was used to pretreat biomasses, the glucose yields after hydrolysis of miscanthus, and triticale hay increased significantly when the catalyst was reused for the second time. However, the hydrolysis yields for switchgrass was similar for both reuses $(53.86 \%, \mathrm{P}=0.42)$. Recently, Tan and Lee (2015) reported the use of solid acid catalyst (Dowex (TM) Dr-G8) to treat macroalgae cellulosic residue at $120^{\circ} \mathrm{C}$ for $30 \mathrm{~min}$ followed by enzymatic hydrolysis for $30 \mathrm{~h}$ using $45 \mathrm{FPU} \mathrm{\textrm {g } ^ { - 1 }}$ of cellulase and $52 \mathrm{CBU} \mathrm{g}^{-1}$ of $\beta$-glucosidase. The authors observed a glucose yield of $94 \%$ even after fifth reuse of the catalyst. Although our glucose is lower when compared to Tan and Lee (2015), it may be noted that the feedstock employed by the authors, i.e., macroalgae cellulosic residue did not contain lignin.

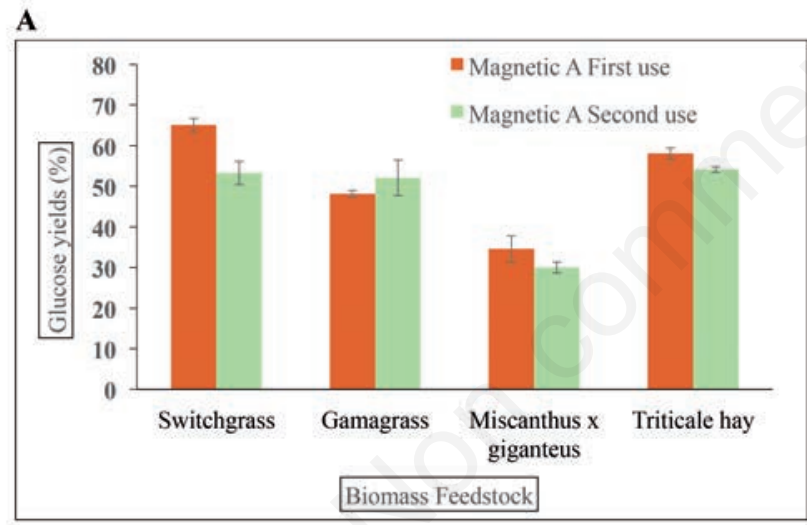

B

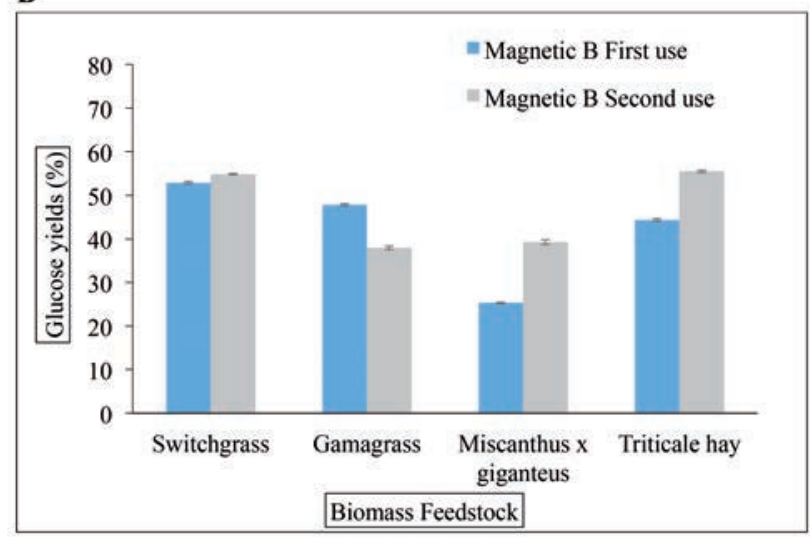

Figure 3. Glucose yields obtained from reusability studies using (A) Magnetic A and (B) Magnetic B catalysts.
In addition, the enzyme loading in our study was is lower than that of Tan and Lee (2015). Further, we also observed xylose in our research (Table 3). Overall, our results suggest that Magnetic A exhibited consistent activity for Gamagrass, Miscanthus $\times$ giganteus and Triticale hay while Magnetic B was observed to be consistent for Switchgrass. In addition, possibility that accumulated iron in wet biomass, which may also have affected the yield. Hence, additional studies on employing surfactants and other agents to minimise the effects of iron are suggested.

\section{Conclusions}

Magnetic sulfonic acid catalysts were found to serve as pretreatment agents for real biomass streams and can provide similar yield of sugars compared with regular catalyst. Although xylose was detected in the liquid after enzymatic hydrolysis, adding xylanases might help in improving the formation of 5 carbon sugars. Although, reusability of magnetic catalysts was tested, future studies are needed to enhance the activities. Magnetic acid catalysts are expected to alleviate problems associated with separation of the catalysts from pre-treated biomass thereby making biomass pre-treatment processes more practical.

\section{References}

Agbor V., Cicek N., Sparling R., Berlin A., Levin D. 2011. Biomass pretreatment: Fundamentals toward application. Biotechnol Adv. 29:675-85.

Alvira P., Tomas-Pejo E., Ballesteros M., Negro M.J. 2010. Pretreatment technologies for an efficient bioethanol production based on enzymatic hydrolysis: A review. Bioresource Technol. 101:4851-61.

Ansanay Y., Kolar P., Sharma-Shivappa R.R., Cheng J.J. 2014. Niobium oxide catalyst for delignification of switchgrass for fermentable sugar production. Industr. Crops Prod. 52:790-5.

Ansanay Y.O., Kolar P., Sharma-Shivappa R.R., Cheng J.J. 2016. Kinetics and mechanism of delignification of switchgrass during niobium oxide pretreatment. Trans. ASABE. 59:737-43.

Chen L., Fu S. 2013. Enhanced cellulase hydrolysis of eucalyptus waste fibers from pulp mill by tween 80 -assisted ferric chloride pretreatment. J. Agr. Food Chem. 61:3293-300.

Chen Y., Sharma-Shivappa R., Chen C. 2007. Ensiling agricultural residues for bioethanol production. Appl. Biochem. Biotech. 143:80-92.

Guo F., Fang Z., Xu C., Smith R. 2012. Solid acid mediated hydrolysis of biomass for producing biofuels. Prog. Energ. Combust. 38:672-90.

Guo H., Lian Y., Yan L., Qi X., Smith R.L. 2013. Cellulose-derived superparamagnetic carbonaceous solid acid catalyst for cellulose hydrolysis in an ionic liquid or aqueous reaction system. Green Chem. 15:2167-74.

Hara M. 2010. Biomass conversion by a solid acid catalyst. Energ. Environ. Sci. 3:601-7.

Kumar P., Barrett D., Delwiche M., Stroeve P. 2009. Methods for pretreatment of lignocellulosic biomass for efficient hydrolysis and biofuel production. Ind. Eng. Chem. Res. 48:3713-29.

Lai D., Deng L., Li J., Liao B., Guo Q., Fu Y. 2011. Hydrolysis of cellulose into glucose by magnetic solid acid. Chem.Sus. Chem. 4:55-8.

Mosier N., Wyman C., Dale B., Elander R., Lee Y.Y. Holtzapple 
M., Ladisch, M. 2005. Features of promising technologies for pretreatment of lignocellulosic biomass. Bioresource Technol. 96:673-6.

Panneerselvam A., Sharma-Shivappa R.R., Kolar P., Clare D.A., Ranney T. 2013a. Hydrolysis of ozone pretreated energy grasses for optimal fermentable sugar production. Bioresource Technol. 148:97-104.

Panneerselvam A., Sharma-Shivappa R.R., Kolar P., Ranney T., Peretti S. 2013b. Potential of ozonolysis as a pretreatment for energy grasses. Bioresource Technol. 148:242-8.

Peña L., Xu F., Hohn K., Li J., Wang D. 2014. Propyl-sulfonic acid functionalised nanoparticles as catalyst for pretreatment of corn stover. J. Biomater. Nanobiotechnol. 5:8-16.

Perlack R.D., Wright L.L., Turhollow A.F., Graham R.L., Stokes B.J., Erbach D.C. 2005. Biomass as feedstock for a bioenergy and bioproducts industry: the technical feasibility of a billionton annual supply. NREL Report. Available from: http://www1.eere.energy.gov/biomass/pdfs/final_billionton_vi sion_report2.pdf

Sluiter A., Hames B.D., Ruiz R., Scarlata C., Sluiter J., Templeton D. 2006. Determination of sugars, byproducts, and degradation products in liquid fraction process samples. Laboratory
Analytical Procedure (LAP), National Renewable Energy Laboratory, Golden, CO, USA.

Sluiter A., Hames, B.D., Ruiz R., Scarlata C., Sluiter J., Templeton D., Crocker D. 2008. Determination of structural carbohydrates and lignin in biomass. Laboratory Analytical Procedure (LAP), National Renewable Energy Laboratory, Golden, CO, USA.

Tan I.S., Lee K.T. 2015. Solid acid catalysts pretreatment and enzymatic hydrolysis of macroalgae cellulosic residue for the production of bioethanol. Carbohyd. Polym. 124:311-21.

Tejirian A., Xu F. 2010. Inhibition of cellulase-catalysed lignocellulosic hydrolysis by iron and oxidative metal ions and complexes. Appl. Environ. Microb. 76:7673-82.

Wang D., Ikenberry M., Pe L., Hohn K. L. 2012. Acid-functionalised nanoparticles for pretreatment of wheat straw. J. Biomater. Nanobiotechnol. 3:342-52.

Xu J., Zhang X., Sharma-Shivappa R.R., Eubanks M.W. 2012. Gamagrass varieties as potential feedstock for fermentable sugar production. Bioresource Technol. 116:540-4.

Zhou C., Xia X., Lin C., Tong D., Beltramini J. 2011. Catalytic conversion of lignocellulosic biomass to fine chemicals and fuels. Chem. Soc. Rev. 40:5588-617. 